\title{
Detection of Legionella pneumophila from Evaporative Coolers Air Conditioners in Khartoum State
}

\author{
Elsanousi R.M.A ${ }^{1, *}$, Elsanousi S.M. ${ }^{2}$ \\ ${ }^{1}$ Department of Microbiology, University of Bahri, Sudan \\ ${ }^{2}$ Department of Microbiology, University of Khartoum, Sudan \\ *Corresponding author: sanousireem@gmail.com
}

\begin{abstract}
This study was designed to detect the prevalence of Legionella pneumophila in evaporative coolers air conditioners in Khartoum State. A total of 525 water samples were collected from water reservoirs of air conditioning systems in the three main cities of Khartoum State (Khartoum, Omdurman and Khartoum North) in the period between March - October, 2012, 2013, 2014, 2015 and 2016. The premises from which the samples were collected were divided into five categories: universities, schools, hospitals, offices and houses (35 samples for each category in the three cities, with a total of 175 samples for each city). Legionella species were isolated from 222 (42.3\%) out of the total samples taken from Khartoum State, which were divided as follows: 75 (33.8\%) from Omdurman, 74 (33.3\%) from Khartoum North and 73 (32.9\%) from Khartoum. Regarding the premises categories, 58 (55.2\%) were from hospitals, 52 (49.5\%) from offices, 41 (39\%) from schools, 38 (36.2\%) from houses and 33 (31.4\%) from universities were positive for Legionella spp. The highest prevalence rate of Legionella spp was found in hospitals (55.2\%), followed by offices (49.5\%), schools (39\%), houses (36.2\%) and universities (31.4\%).
\end{abstract}

Keywords: Legionella pneumophila, evaporative coolers air conditioners, water samples

Cite This Article: Elsanousi R.M.A, and Elsanousi S.M., "Detection of Legionella pneumophila from Evaporative Coolers Air Conditioners in Khartoum State.” American Journal of Microbiological Research, vol. 5, no. 6 (2017): 138-141. doi: 10.12691/ajmr-5-6-4.

\section{Introduction}

An evaporative cooler is a device that cools air through the evaporation of water. The temperature of dry air can be dropped significantly through the phase transition of liquid water to water vapor (evaporation) [16].

Legionnaires' disease acquired its name in July 1976 when an outbreak of pneumonia occurred among people attending a convention of the American Legion at the Bellevue - Stratford Hotel in Philadelphia. On January 1977 the causative agent was isolated from the cooling towers of the hotel's air conditioning system, identified and named Legionella [19].

Legionella are Gram negative bacilli, non capsulated and non - spore forming, most species exhibit motility and have non fermentative metabolism [38]. The bacteria are ubiquitous, which found in environmental water sources such as rivers, lakes and soil. The organism passes into sites that constitute an artificial reservoir like piped water in towns and cities, water net works, water systems in individual buildings and cooling towers [33]. The organisms do not multiply below $20^{\circ} \mathrm{C}$ and are killed within a few minutes at temperatures above $60^{\circ} \mathrm{C}$ [31]. Environmental surveillance of Legionella is the standard culture technique. Recently Real - time - PCR method for rapid detection and quantification of Legionella in water samples was developed [22,37]. All Legionella organisms require L- cysteine and iron for primary isolation and subcultures. Buffered Charcoal Yeast Extract (BCYE) agar containing L- cysteine and iron as well as $\alpha$ - ketoglutarate. It can be made more selective by the addition of antibiotics for Legionella spp selection [14,32]. Legionella spp prefer $80-90 \%$ humidity with $2-5 \% \mathrm{CO}_{2}$. They are catalase positive and do not ferment or oxidize sugars. Legionella pneumophila is oxidase positive but other Legionella species are variable in oxidase activity, Most Legionella spp produce gelatinase and $\beta$ - lactamase enzymes. [3]. Legionella bacteria multiply within amoebae, specially, when environmental conditions are unfavorable [15]. Also it can grow and multiply intracellularly within human alveolar macrophages. [2]. The term Legionellosis, is collectively refers to Legionnaires' disease and Pontiac fever [18]. Inhalation of contaminated aerosols is the most commonly accepted mechanism of infection [9]. The potential health risk of Legionella to humans is theoretically associated with cells densities in a range between $10^{4}-10^{5} \mathrm{CFU}$ per liter of water [4,23]. Most community and nosocomial cases of Legionnaires' disease are typically associated with cooling towers [27]. Legionella spp. are responsible for 1 to $5 \%$ of cases of community - acquired pneumonia (CAP) [5,35]. Immuno suppression, chronic lung disease, cigarette smoking and old in age are risk factors for the disease, signs and symptoms are non specific and do not distinguish 
Legionella infection from other common causes of pneumonia. [10].

\section{Material and Methods}

\subsection{Samples Collection}

A total of 525 water samples were collected from evaporative air conditioning systems from Khartoum State, which distributed according to the statistic data with a rate of 175 samples for each city; Khartoum, Omdurman and Khartoum North, including five categories for each city: universities, schools, hospitals, offices and houses which divided on 35 samples for each category in the three cities of the Khartoum State, the samples were taken under aseptic conditions, using sterile syringes and sterile containers. The specimens were labeled, put into thermos containing ice and transferred to the research laboratory for bacteriological examination. Samples were tested for $\mathrm{pH}$ and temperature during sampling. Also the status and type of the air conditioners were investigated. Samples were taken according to geographical distribution of the cities including the four directions and following the microbiological quality control measures. Also water distribution in each area was considered. Samples that were collected from offices included public offices like commercial offices, markets, pharmacies and others according to the geographic distribution of the areas. Firstly, for proper evaluation we took samples in different volumes; $1000 \mathrm{ml}, 500 \mathrm{ml}, 100 \mathrm{ml}, 50 \mathrm{ml}$ and $20 \mathrm{ml}$, but most samples were taken as $20 \mathrm{ml}$ of evaporative cooling conditioners water reservoirs.

\subsection{Bacterial Isolation}

Five $\mathrm{ml}$ of each water sample were centrifuged at 4000 rpm for 10 minutes using a cold centrifuge. The sediment was inoculated onto Buffered Charcoal Yeast Extract Agar BCYE - $\alpha$ medium and Glycine Vancomycin Polymxin Cycloheximide Medium (G V P C Medium) (Oxoid Laboratories, London). Inoculated media were incubated at $37^{\circ} \mathrm{C}$, in an atmosphere of $5-10 \% \mathrm{CO}_{2}$ (using the candle jar) and humidity using wet cotton swamp on water in a Petri Dish, for 3 - 7 days.

\subsection{Bacterial Identification}

Cultures were examined by Gram stain technique. And sub cultured on Blood agar to ensure its negative growth. Primary identification was done by light microscopy using Gram stain technique, Secondary identification was done by biochemical tests like catalase, oxidase and gelatin hydrolysis tests, which were performed according to Barro and Feltham [3]. Purified isolates were confirmed using Real time PCR.

\subsection{Real Time PCR}

This procedure was done following manufacture instructions- (Sacace Biotechnologies, Italy) - Real Time PCR Kit for quantitative detection of Legionella pneumophila
- Complete Real Time PCR test with DNA purification kit (TB50-50FRT). Pure colonies suspected for Legionella pneumophila were emulsified in $0.5 \mathrm{ml}$ saline solution. 50 $\mu \mathrm{l}$ of the suspension was used for DNA extraction. Required quantity of PCR - mix-1 reaction tubes were prepared for samples and controls. Seven $(7 \mu \mathrm{l})$ of PCR mix - 2 was added on the wax surface in addition to ten $(10 \mu \mathrm{l})$ of extracted DNA to appropriate tube. Ten $(10 \mu \mathrm{l})$ of DNA - buffer was added to the tube labeled to amplification negative control. Also ten $(10 \mu \mathrm{l})$ of QS1, QS2 and QS3, were added to the tubes labeled to amplification positive controls. All of the mentioned tubes were inserted to the thermo cycler for amplification.

\subsection{Data Analysis}

The results were subjected to statistical analysis in the form of frequencies and percentages. The significance of these frequencies was tested using chi- square test. The data were analyzed using SPSS 21 with reference P-value $\leq 0.05$.

\section{Results}

Khartoum State gave results as follows:

A total of 222(42.3\%) positive samples, including, (33.8\%) for Omdurman, (33.3\%) for Khartoum North and (32.9\%) for Khartoum, which calculated out of 222 positive samples obtained from 525 collected samples. (Table 2) All samples were between $14^{\circ} \mathrm{C}-37^{\circ} \mathrm{C}$, during sampling and showed $\mathrm{pH}$ between 6.7- 8.6 for most of the samples. Also all positive samples showed growth on BCYE - $\alpha$ medium and GVPC medium and gave negative growth on Blood Agar medium. All Legionella spp isolates revealed negative reaction to Gram stain technique and positive reactions to: catalase, oxidase and gelatin hydrolysis tests. $63 \%$ from 38 randomly selected Legionella spp isolates showed positive results for Legionella pneumophila using Real Time PCR technique (Table 1). Khartoum State positive results (42.3\%) were divided as follows: Omdurman city gave the highest prevalence rate of Legionella spp, which was $14.3 \%$, followed by Khartoum North (14.1\%) and Khartoum (13.9\%) (Table3). Hospitals category showed: $23.8 \%$ for Omdurman hospitals, $16.2 \%$ for Khartoum hospitals and $15.2 \%$ for Khartoum North hospitals, with a total of $55.2 \%$ positive samples. The second higher prevalence rate of Legionella spp was obtained from the offices category, which revealed a rate of $49.5 \%$ for the three cities, with $22 \%$ for Khartoum, $17 \%$ for Khartoum North and $10.5 \%$ for Omdurman. The third category that gave high level of Legionella spp was the schools, which showed $39 \%$, for the three cities, with a rate of: $14.3 \%$ for Khartoum North, $13.3 \%$ for Khartoum, and $11.4 \%$ for Omdurman. The forth category was the houses which revealed 36.2\% of Legionella spp, with a rate of $12.4 \%$ for both Khartoum North and Omdurman and $11.4 \%$ for Khartoum. The lowest rate of Legionella spp was reported in universities as: $31.4 \%$ for the three cities with a rate of $13.3 \%$ for Omdurman, $11.4 \%$ for Khartoum North and 6.7\% for Khartoum (Table 4). 
Table 1. Quantitative Real Time PCR results of Legionella pneumophila isolated from four water samples obtained from evaporative air conditioning systems in Khartoum State

\begin{tabular}{|c|c|c|c|}
\hline $\begin{array}{c}\text { Sample } \\
\text { Name }\end{array}$ & $\begin{array}{c}\text { Standard } \\
\text { Concentration }\end{array}$ & $\begin{array}{c}\text { Calculated } \\
\text { Concentration }\end{array}$ & Ct \\
\hline QS1 & $6.23 \times 10^{6}$ & $6.23 \times 10^{6}$ & 5.98 \\
\hline QS2 & $1.70 \times 10^{5}$ & $1.70 \times 10^{5}$ & 22.12 \\
\hline QS3 & $4.00 \times 10^{3}$ & $4.00 \times 10^{3}$ & 35.03 \\
\hline NTC & - & - & - \\
\hline 9 & & $3.56 \times 10^{6}$ & 15.67 \\
\hline 13 & & $1.09 \times 10^{5}$ & 25.46 \\
\hline 21 & & $1.60 \times 10^{5}$ & 22.29 \\
\hline 43 & & $5.29 \times 10^{6}$ & 13.12 \\
\hline
\end{tabular}

QS: Positive standard control, NTC: Negative Standard control, Ct: Cycle threshold.

Table 2. Prevalence of $L$. pneumophila in water samples collected from evaporative air conditioning systems with their rate in each city of Khartoum State

\begin{tabular}{|c|c|c|c|c|}
\hline \multirow{2}{*}{ City } & \multicolumn{2}{|c|}{$\begin{array}{c}\text { Positive samples } \\
\text { (out of 222) }\end{array}$} & \multicolumn{2}{c|}{$\begin{array}{c}\text { Negative samples } \\
\text { (out of 303) }\end{array}$} \\
\cline { 2 - 5 } & Number & $\%$ & Number & $\%$ \\
\hline Omdurman & 75 & 33.8 & 100 & 33 \\
\hline Khartoum north & 74 & 33.3 & 101 & 33.3 \\
\hline Khartoum & 73 & 32.9 & 102 & 33.7 \\
\hline
\end{tabular}

Table 3. Percentages and calculation of the total of positive and negative samples in the three cities of Khartoum State from the total number of collected samples

\begin{tabular}{|l|c|c|c|c|}
\hline \multirow{2}{*}{ City } & \multicolumn{2}{|c|}{$\begin{array}{c}\text { Positive samples } \\
\text { (out of 525) }\end{array}$} & \multicolumn{2}{c|}{$\begin{array}{c}\text { Negative samples } \\
\text { (out of 525) }\end{array}$} \\
\cline { 2 - 5 } & Number & \% & Number & \% \\
\hline Omdurman & 75 & 14.3 & 100 & 19.1 \\
\hline Khartoum North & 74 & 14.1 & 101 & 19.2 \\
\hline Khartoum & 73 & 13.9 & 102 & 19.4 \\
\hline Total & 222 & 42.3 & 303 & 57.7 \\
\hline
\end{tabular}

Table 4. Prevalence of $L$. pneumophila in water samples collected from evaporative air conditioning systems including their rate in each group under study in Khartoum State

\begin{tabular}{|c|c|c|c|c|}
\hline $\begin{array}{c}\text { Categories } \\
\text { (out of 105) }\end{array}$ & Khartoum & $\begin{array}{c}\text { Khartoum } \\
\text { north }\end{array}$ & Omdurman & $\begin{array}{c}\text { Total \% of } \\
\text { positive } \\
\text { samples }\end{array}$ \\
\hline Universities & $6.7 \%$ & $11.4 \%$ & $13.3 \%$ & $31.4 \%$ \\
\hline Schools & $13.3 \%$ & $14.3 \%$ & $11.4 \%$ & $39 \%$ \\
\hline Hospitals & $16.2 \%$ & $15.2 \%$ & $23.8 \%$ & $55.2 \%$ \\
\hline Offices & $22 \%$ & $17 \%$ & $10.5 \%$ & $49.5 \%$ \\
\hline Houses & $11.4 \%$ & $12.4 \%$ & $12.4 \%$ & $36.2 \%$ \\
\hline
\end{tabular}

\section{Discussion}

In general view of this study, it was found that hospitals' evaporative cooling systems reported the highest prevalence rate (55.2\%) of Legionella species among all categories under study, which agrees with many studies on hospitals that reported evidence to Legionella species in hospitals environments and demonstrated their role in hospital acquired pneumonia, like a previous study done in India by Anbumani, Gururajkumar and Chaudhury [1] for the isolation of Legionella pneumophila from clinical and environmental sources in a tertiary care hospital. They found that Legionella pneumophila was present in the hospital environment and was the aetiological agent of lower respiratory tract infection in $2.55 \%$ of the patients.
Findings of our study substantiate the study of Leoni et al. [24], who detected Legionella species in $40 \%$ of domestic, hotel and hospital hot water systems in Italy. Legionella pneumophila isolated from $33.3 \%$ of the samples and the highest colonization was found in the hot water systems of hospitals. Another study in Iran carried by Ghotaslou et al. [20], detected Legionella contamination in Tabriz hospitals using PCR assay where they reported that 10 of 140 (7.1\%) were positive for Legionella, with Legionella pneumophila detection in 4 (2.85\%) of the water samples. This study concluded that hospitals potable system were the primary reservoirs for Legionnaires' disease and Legionella species, were presented in aquatic hospitals environment. Such hospital systems are also the main cause of nosocomial infection through aspiration [25]. Offices group revealed the second highest rate of Legionella prevalence. This result is important because it covered different types of premises under this category, especially when we are considering the proportion of community acquired pneumonia (CAP) that results in severe pneumonia is higher for Legionnaires' disease than for other causes; with a consequently higher mortality rate [17]. Community acquired pneumonia has a high rate of hospital admission, with less than $1 \%$ being managed at home. Legionnaires' disease can account for up to $30 \%$ of community acquired pneumonia requiring admission to intensive care units [26,39]. Infection with Legionella requires both proliferation and exposure. Potable water systems containing Legionella are a significant cause of sporadic cases of legionellosis acquired in the community $[4,34,36,40]$. Legionnaires' disease is thought to be rare in children but one study identified 76 cases of Legionella infection in children [21]. Schools group demonstrate a rate of $39 \%$ of Legionella spp prevalence in air conditioners, which may become a threat if not controlled. Results of this study revealed $36.2 \%$ Legionella positive growth for the houses, which is a higher result when compared with the results obtained by Dimitriadi and Velonakis [13], whom detected Legionella species from houses domestic water in Greece in only $17 \%$ from a total of 100 collected samples. Our results was almost similar to that of a previous study done by Burak and Zeybek [6], who collected 122 samples from hot water and swabs from the showers in 61 houses in Istanbul, who isolated Legionella pneumophila from 13 (21.3\%) of the houses. The lowest prevalence rate of Legionella spp. in this study was found in the universities category, with 31.4\% Legionella positive growth. This seems to be similar to the results obtained by Chin et al. [8] who isolated Legionella spp from cooling towers and potable water systems in a university campus in Kuala Lumpur with prevalence rate of $23.5 \%$ for Legionella pneumophila. $63 \%$ from a total of 38 selected isolates gave positive results for Legionella pneumophila using Real-Time PCR technique, which is considered a rapid diagnostic method in comparison with different PCR assays [11].

\section{Conclusion}

In conclusion, the rate of the prevalence of Legionella spp. in evaporative cooler air conditioning systems in Khartoum State, found in this study indicates a 
considerable prevalence of this pathogenic organism in the environment which may result in a great biological burden leading to serious outbreaks if measures of prevention and control were not taken.

\section{References}

[1] Anbumani, S., Gururajkumar, A. and Chaudhury, A. (2010). Isolation of Legionella pneumophila from clinical And environmental sources in a tertiary care hospital, Indian. J. Med. Res. 131: 761-764.

[2] Barker, J., and Brown, M. R. W. (1994). "Trojan horses of the microbial world: protozoa and the survival of bacterial pathogens in the environment." Microbiol 140 (6): 1253-1259.

[3] Barrow, G. I. and Feltham, R. K. A. (2003). Cowan and Steel's Manual for the identification of the Medical Bacteria, 3rd "edition. Cambridge University Press, Cambridge, U. K.

[4] Best, M., Yu, V. L., Stout, J., Goetz,A., R. R. Muder,R.R., and Taylor, F (1983). "Legionellaceae in the hospital water-supply. Epidemiological link with disease and evaluation of a method for control of nosocomial legionnaires disease and Pittsburgh pneumonia,” The Lancet, 2(8345). 307-310.

[5] Breiman, F. R. and Butler, J. C. (1998). Legionnaires'disease: clinical, epidemiological, and public health perspectives. Semin Respir Infect 13 (2): 84-89.

[6] Burak, D. M. and Zeybek, Z (2011). Investigation of Legionella pneumophila and free living amoebas in the domestic hot water systems in Istanbul. Turk J Bio (135). 679-685.

[7] Cheesbrough, M., (2000). District Laboratory Practice in Tropical Countries, Part 2 Second Edition,Cambridge university press.

[8] Chin, k. s., Rosli, A. A., Wee, C. S. L. and Ngeow, Y. F. (2005): isolation of Legionella from cooling towers and potable water systems in hospital and non-medical buildings in a university campus, JUMMEC 2003-2005. (8): 23-27.

[9] Cianciotto, N. P. (2001): Pathogenicity of Legionella pneumophila. Int. J .Med. Microbiol. 291(5): 331-343.

[10] Den Boer, J. W. and Yzerman, E. P. F. (2004). Diagnosis of Legionella infection in Legionnaires' disease. Eur. J. Clin. Microbiol. Infect. Dis. 23 (12): 871-878.

[11] Devos, L., Clymans, K., Boon, N. and Verstraete, W (2005). Evaluation of nested PCR assays for the detection of Legionella pneumophila in a wide range of aquatic samples. J. Appl. Microbiol (99). 916-925.

[12] Diederen, B. M. W, deJong, C. M. A., Marmouk, F.,.Kluytmans, J. A. J. W., Peeters, M. F. andZee1, A. V (2007). Evaluation of realtime PCR for the early detection of Legionella pneumophila DNA in serum samples. J. of Med. Microbiol. 56(1). 94-101.

[13] Dimitriadi, D. and Velonakis, E. (2014). Detection of Legionella spp. From Domestic Water in the Prefecture of Arta, Greece, J. of Path., ID 407385, 5.

[14] Edelstein, P. H (1981). Improved semi selective medium for isolation of Legionella pneumophila from contaminated clinical and environmental specimens. J. clin. Microbiol. 14(3). 298-303.

[15] Edelstein, P.H., Cianciotto, N. P., Mandell, G. L., Bennett, J. E. and Dolin, R. (2005). Legionella Infections. principles and practice of infectious diseases.Sixth .ed. Philadelphia, PA Elsevier Inc. 2711-2724.

[16] Essick, B (1945). Pad for evaporative coolers, filled Aug. 30, 1944, patented Dec1945. United state patent office, 2, 391, 558 Pad for evaporative coolers, Bryant Essick, Los Angeles, Calif. Application Augest 30, 1944, Serial No 551, 982.

[17] Ewig, S. and Torres, A. (1999). Severe community-acquired pneumonia. Clin. Ches. Med., 20 (3): 575-587.

[18] Fields, B. S., Benson, R. F. and Besser, R. E. (2002). Legionella and Legionnaires' disease: 25 years of investigation. Clin. Microbiol. Rev., 15 (3): 506-526.

[19] Fraser, D. W., Tsai, T. R., Orenstein, W., Parkin, W., E., Beecham, H. J., Sharrar, R.G., Harris, J., Mallison, G.F., Martin, S.M., McDade, J.E., Shepard,C.C. and Brachman, P.S (1977). Legionnaires' disease. description of an epidemic of pneumonia. $N$. Engl. J. med. 297(22). 1189-1197.
[20] Ghotaslou, R., Sefidan, F. Y., Akhi, M. T., Soroush, M. H. and Hejazi, M. S (2013). Detection of Legionella Contamination in Tabriz Hospitals by PCR Assay. Adv. Pharma. Bull. 3(1). 131-134.

[21] Greenberg, D., Chiou, C. C., Famigilleti, R., Lee, T. C. and Yu, V. L. (2006). Problem pathogens: paediatric legionellosis implications for improved diagnosis. Lancet. Infect. Dis. 6(8): 529-535.

[22] Joly, P., Falconnet, P. A., Andre, J., Weill, N., Reyrolle, M. Vandenesch F., Maurin, M., Etienne, J. and Jarraud,S., (2006). Quantitative real-time PCR for Legionella- environmental water samples. App. Environ. Microbiol. 72 (4): 2801-2808.

[23] Kool, J. L., Bergmire-Sweat, D., Butler, J.C., Brown, E.W., Peabody, D.J., Massi, D.S,, Carpenter, J.C., Pruckler, J.M., Benson, R.F. and Fields, B.S (1999). "Hospital characteristics associated with colonization of water systems by Legionella and risk of nosocomial Legionnaires' disease. a cohort study of 15 hospitals." Infect. Control. hosp. Epidemiol. 20 (12). 798-805.

[24] Leoni. E., De luca. G., Legnani. p. p, Sacchetti, S., Stampi, S . and Zanetti. F. (2005). Legionella waterline colonization: detection of Legionella species in domestic, hotel and hospital hot water systems. J. of App. Microbiol, 98, 373-379.

[25] Lowry, P. W. and Tompkins, L. S (1993). Nosocomial legionellosis. a Review of pulmonary and extra pulmonary syndromes. Am. J. of Infect. Conol, 21(1). 21-27.

[26] Macfarlane, J. T (1993). Prospective study of aetiology and outcome of adult lower respiratory- tract infections in the community. Lancet, 341 (8844). 511-514.

[27] Nguyen, T. M., Ilef, D., Jarraud, S., Rouil,R., Campese, c., Che, D. Haeghebaert, S. Ganiayre, F., Marcel, F., Etienne, J., and Desenclos, J.C. (2006). A community-wide outbreak of Legionnaires disease linked to industrial cooling towers - how can far contaminated aerosols spread? J. Infect Dis 193(1): 102-111.

[28] Nintasen, R., Utra rachkij, F., Siripanichgon, K., Bhumiratana, A., Suzuki, Y. and Suthien kul, O (2007). (mip) gene-specific nested polymerase chain reaction. Microbiol Immunol. Enhancement of Legionella pneumophila culture isolation from Micro environments by macrophage infectivity potentiator 51.777-785.

[29] Pedro-Botet, M. L. and Yu, V. L (2009). Treatment strategies for Legionella infection. Expert. Opin. Pharma. 10 (7). 1109-1121.

[30] Roig, J. and Rello, J. (2003). Legionnaires' disease: a rational approach to therapy. J .Antimicrob. Chemother. 51(5): 1119-1129.

[31] Sheehan, K. B., Henson, J. M. and Ferris, M. J. (2005). Legionella species diversity in an acidic biofilm community in Yellow stone National Park. Appl. Environ. Microbiol; 71(1): 507-511.

[32] Smith, M. G (1982). A simple disc technique for the presumptive identification of Legionella pneumophila." J. Clin. Pathol. 35(12). 1353-1355.

[33] Steele, T. W., Moore, C. V. and Sangster, N. (1990). Distribution of Legionella longbeachae serogroup 1 and other legionellae in potting soils in Australia. Appl Environ Microbiol 56(10): 2984-2988.

[34] Stout, J. E., Yu, V. L. and Best, M. G (1985). Ecology of Legionella pneumophila within water distribution systems. Applied and Environment. Microbiolo, 49(1). 221-228.

[35] Van der Eerden, M. M., Vlaspolder, F., deGraaff, C. S., Groot, T., Jansen, H. M. and Boersma, W. G. (2005). Value of intensive diagnostic microbiological investigation in low- and high-risk patients with community acquired pneumonia. Eur. J. Clin. Microbiol. Infect. Dis., 24(4): 241-249.

[36] Venezia, R. A (1994). Nosocomial legionellosis associated with aspiration of naso gastric feedings diluted in tap water. Infection Control and Hospital Epidemiology, 15(8). 529-533.

[37] Welling hausen, N., Frost, C, and Marre. R. (2001). "Detection of Legionellae in hospital water samples by quantitative real-time Light Cycler PCR,” Appl Environ Microbiol 67(9): 3985-3993.

[38] Winn, W. C. Jr. (1988). Legionnaires disease: Historical Perspective Microbiol Rev. 1(1):60-81.

[39] Woodhead, M. A (1987). Prospective study of the aetiology and outcome of pneumonia in the community. Lancet, 1(8534). 671-674.

[40] Yu, V. L (1993). Could aspiration be the major mode of transmission for Legionella? American Journal of Medicine. 95(1) 13-15. 